\title{
Oil Machinery Fluid of Craniopharyngioma. Biochemical Analysis: Clinico-Pathological Correlation
}

\author{
Martha Lilia Tena Suck ${ }^{1,3, *}$, Andrea Y. Morales del Ángel ${ }^{2}$, Ma. Elena Hernández-Campos ${ }^{3}$, \\ Manuel Castillejos-López ${ }^{4}$, Georgina González-Ávila ${ }^{5}$ \\ ${ }^{1}$ Departamento de Neuropatología, Instituto Nacional de Neurología y Neurocirugía, Cuidad de México, México, Av. Insurgentes sur no 3788 , \\ Colonia la Joya, delegación Tlalpan, México D. F. Cp. 14269, y Escuela Superior de Medicina, Estudios de Post-grado, Instituto \\ Politécnico Nacional, Ciudad de México \\ ${ }^{2}$ Laboratorio de Nanotecnología, Instituto Nacional de Neurología y Neurocirugía, Cuidad de México, México \\ ${ }^{3}$ Escuela Superior de Medicina, Estudios de Post-grado, Instituto Politécnico Nacional, Ciudad de México \\ ${ }^{4}$ Departamento de Epidermiología Clínica, Instituto Nacional de Enfermedades Respiratorias, Ciudad de México, México \\ ${ }^{5}$ Laboratorio de Oncología biomédica, Instituto Nacional de Enfermedades Respiratorias, Ciudad de México, México
}

\section{Email address:}

mltenasuck@hotmail.com (M. L. T. Suck),yossa0713@hotmail.com (A. Y. M. del Ángel), mayec@hotmail.com (M. E. Hernández-Campos), manuelcastillejos@gmail.com (M. Castillejos-López),ggonzalezavila@yahoo.com (G. González-Ávila)

\section{To cite this article:}

Martha Lilia Tena Suck, Andrea Y. Morales del Ángel, Ma. Elena Hernández-Campos, Manuel Castillejos-López, Georgina González-Ávila. Oil Machinery Fluid of Craniopharyngioma. Biochemical Analysis: Clinico-Pathological Correlation. American Journal of Clinical and Experimental Medicine. Vol. 3, No. 2, 2015, pp. 52-58. doi: 10.11648/j.ajcem.20150302.11

\begin{abstract}
Craniopharyngiomas are histologically benign tumors, but they have a tendency to become adherent around the pituitary gland and pituitary stalk, including the optic nerves, optic chiasm, intracranial arteries and the brain itself. 15 cases of craniopharyngiomas were included in this study. The oil fluid biochemical analysis was made; glucose, cholesterol, lipids, proteins, lactate dehydrogenase, globulins, calcium, sodium, etc. and Western Blot was performed for 2 and 9 metalloproteins. Clinicopatological correlation was made. Groups were divided in recurrent and non-recurrent tumor. The age of patient ranged from 18 to $51 \mathrm{yr} 11$ (mean of 30yrs). 11 (73\%) were females and 4 (27\%) were male. Recurrence was in 8 (53\%) cases. We analyze the mean of laboratory results obtaining normal to low serum values for ions and high fluid values for all the elements studied. There was no statically significance between them, but we observe the patients which had a big tumor, recurrence and green color oil fluid presented high levels of these components. By the other hand, little not recurrent tumors and with a yellow oil fluid aspect, had low serum values of alkaline phosphatase, serum glutamic oxaloacetic and glutamic-pyruvic transaminases. The output of these components in the Central Nervous System can be toxic and produce more inflammatory response.
\end{abstract}

Keywords: Craniopharyngioma, Oil Fluid, Oil Machinery, Oil Content, 2 and 9 Metalloproteinase

\section{Introduction}

Craniopharyngiomas (CFs) are intracranial tumors that are typically cystic and solid in structure. They occur most commonly in childhood and adolescence and in later adult life after age 50 years. ${ }^{1}$ They account for $2-4 \%$ of primary brain tumors. Craniopharyngioma is a rare, usually a suprasellar neoplasm, which can be cystic, they develop from nests of epithelium derived from Rathke's pouch. ${ }^{1}$

The pathogenesis of craniopharyngioma has currently debated between two primary hypotheses: one describes tumor origin as ectodermal remnants of Rathke's pouch; the second one, that craniopharyngioma represents a malformation of residual embryonal epithelium from the anterior pituitary gland and infundibulum. ${ }^{2-4}$

They classified by histology as benign; Two principal patterns of craniopharyngioma are recognized: papillary and adamantinomatous. ${ }^{1}$ CFs are typically very slow growing tumors. The histologic pattern consists of nesting of squamous epithelium bordered by radially arranged cells. ${ }^{1}$ On macroscopic examination, CFs are cystic or partially cystic with solid areas. The cysts are usually filled with a yellow, viscous fluid, which is rich in cholesterol crystals. CFs usually presented as a single large cyst or multiple cysts filled with a turbid, proteinaceous, brownish yellow material that glitters owing to the high content of floating cholesterol 
crystals and frequently accompanied by calcium deposition and may have a microscopic papillary architecture. On light microscopy, the cysts lined by stratified squamous epithelium. $^{1}$

Keratin pearls, ghost cells, goblet cells, inflammation, dystrophic calcifications can also be seen. ${ }^{3-5}$ Although their histologically benign, these tumors frequently recur after treatment, it behaves aggressively as a malignant tumor due to invasion to the hypothalamus and visual pathways. ${ }^{5-7}$

The purpose of this study was to evaluate the possible role of blood-brain barrier disruption in oil fluid content of cyst formation in craniopharyngioma. Biochemical analysis, also 2 and 9 metalloproteinase expression in oil machinery fluid of cyst structures of craniopharyngioma was studied. Clinicopatological correlation was made.

\section{Material and Methods}

The oil content of cystic structures of was obtained during surgical procedure. 15 cases were included in this study. The oil fluid was sent to clinical pathology laboratory for the biochemical analysis; glucose, total proteins, lactate deshidrogense, globulins, calcium, sodium, magnesium, potasium, hemoglobin, etc. were analyzed.

All lipid measurements were performed in the same central laboratory. Serum concentrations of total cholesterol, ${ }^{8}$ high density lipoprotein (HDL) low density lipoprotein (LDL), cholesterol, ${ }^{9}$ and triglycerides ${ }^{10}$ were measured directly and expressed as mmol/l, and Western Blot was performed for 2 and 9 metalloproteins. Clinical data was obtained from patients' dossier (age gender, tumor size, recurrence, brain invasion), histopathological tissues were fixed in formalin and embedded in paraffin and then sectioned ( $4 \mu \mathrm{m}$ thick). All samples were stained with hematoxylin and eosin stain (inflammation, wet keratins, ghost cells, dystrophic calcifications, brain invasion and Rosenthal fibers in the boundary) analysis reviewed. Tumor groups were divided by recurrence and non-recurrence tumors. The oily contents biochemical values were compared with the patient's serum.

\subsection{Gelatin Zymography Assay}

Cerebrospinal fluid (CSF) proteins were determined by the bicinchoninic acid protein assay (Pierce Chemical Co., Rockford, III., USA). ${ }^{11}$ Substrate gel electrophoresis was carried out in $8 \%$ SDS-PAGE gels containing $0.1 \%$ pig skin gelatin (Sigma, St Louis MO, USA). ${ }^{12}$ Thirty micrograms of CSF protein from each patient were applied per lane under nondenaturating conditions. After electrophoresis, the gels were washed in $2.5 \%$ Triton $\mathrm{X}-100$ for $30 \mathrm{~min}$ and then incubated in $50 \mathrm{mM}$ Tris- $\mathrm{HCl}, 0.15 \mathrm{mM} \mathrm{NaCl}, 20 \mathrm{mM} \mathrm{CaCl}$, and $0.02 \%$ sodium azide, $\mathrm{pH} 7.4$, at $37^{\circ} \mathrm{C}$ for $24 \mathrm{~h}$. Gels were stained with Coomassie Blue R-250 (Bio-Rad Laboratories, Hercules, CA, USA)[12]. Gelatinase activity was visualized as transparent bands against a blue background on the stained SDS-PAGE gelatin gels.

\subsection{Statistical Analysis}

The statistical significance between median, means and standard derivation (SD) was valuated. The statistical differences between different groups were assessed by 2-way analysis of variance. Statistical analyses were obtained using SPSS v.20 software for Windows (SPSS, Chicago, Illinois). Comparisons of proportions were performed using the Fisher exact and Chi-square tests. Significance was accepted with $\mathrm{P}$ values of $<0.05$. To adjust ages and gender differences a multiple linear regression was performed (MLR); differences were only shown as significant when MLR analysis had demonstrated an independent effect of age and gender. Data was expressed as median (90\% confidence limits) as appropriate.

\section{Results}

The clinical characteristic and histological features of the cases are shown in table 1 . The age of patient ranged from 18 to $51 \mathrm{yrs}$. 11(mean of 30yrs). $11(73 \%)$ were females and 4 $(27 \%)$ were male. Recurrence was presented in $8(53 \%)$ cases According the characteristic of the oil fluid, 7 cases were green and 8 yellow. Histologically observation; brain invasion in 9 (60\%) (Fig.1a) and inflammation in 9(60\%) (Fig. 1b). We could observe macrophages in 10 (67\%)(Fig. 1c) and hemosideroghages (Fig. 1d), clef cholesterol and granulomas formation in $5(33 \%)$ (Fig.1e), dystrophic calcification in $10(67 \%)$ (Fig.1f) cases and proteinaceous material contained in cyst structures in all cases (Fig. 1g). Also we observed this oil fluid in the brain tissue as well as inside of the vessels (Fig. 1h). The tumor ranged size varied from 34 to $45 \mathrm{~mm}$ (mean of $42.67 \pm 7.267$ ). There was a lineal association between age and brain invasion $(p=.001)$, tumor size, clef cholesterol and granulomas formation $(\mathrm{p}=.003$ respectively) and with brain invasion $(\mathrm{p}=.004)$ Recurrence was associated with inflammation and Rosenthal fibers $(p=.005)$ and brain invasion $(p=.001)$. We observe older patients had more invasion and tumor recurrence in a larger size with more inflammation, presence of Rosenthal fibers, as well as cholesterol and granulomas formations.

Table 1. Showed the clinic pathological characteristics of the patients with craniopharingioma included in this study.

\begin{tabular}{|c|c|c|c|c|c|c|c|c|c|c|c|c|c|c|}
\hline Cases & Age & Gender & T. size & RC & BI & IR & RF & Ma & Hma & DC & WK & CHL & GR & OF \\
\hline Case 1 & 30 & Female & 34 & Non & Non & Non & yes & yes & non & non & yes & yes & yes & green \\
\hline Case 2 & 18 & Female & 35 & Non & Non & Non & non & non & non & non & non & non & non & yellow \\
\hline Case 3 & 24 & Female & 46 & Yes & Yes & yes & yes & yes & non & non & non & non & non & green \\
\hline Case 4 & 19 & Male & 45 & Yes & Yes & yes & yes & yes & non & non & non & non & non & green \\
\hline Case 4 & 34 & Male & 45 & Yes & Yes & yes & yes & yes & non & non & yes & yes & yes & yellow \\
\hline
\end{tabular}




\begin{tabular}{|c|c|c|c|c|c|c|c|c|c|c|c|c|c|c|}
\hline Cases & Age & Gender & T. size & RC & BI & IR & RF & Ma & Hma & DC & WK & CHL & GR & OF \\
\hline Case 6 & 50 & Female & 53 & Yes & Yes & yes & yes & yes & non & non & yes & yes & yes & green \\
\hline Case 7 & 26 & Female & 34 & Yes & Yes & yes & yes & yes & yes & yes & yes & yes & yes & yellow \\
\hline Case 8 & 27 & Male & 53 & Yes & Yes & yes & yes & yes & yes & yes & yes & yes & yes & green \\
\hline Case 9 & 51 & Female & 34 & Non & Non & Non & non & yes & non & non & non & non & non & yellow \\
\hline Case 10 & 38 & Male & 35 & Non & Non & Non & non & non & non & non & non & non & non & yellow \\
\hline Case 11 & 31 & Male & 37 & Non & Non & Non & non & non & non & non & non & non & non & Yellow \\
\hline Case 12 & 21 & female & 35 & Non & Non & Non & non & non & non & non & non & non & non & Yellow \\
\hline Case 13 & 25 & female & 43 & Non & Yes & Yes & yes & yes & non & non & non & non & non & yellow \\
\hline Case 14 & 32 & female & 45 & Yes & Yes & Yes & yes & yes & yes & yes & yes & yes & non & Green \\
\hline Case 15 & 38 & female & 46 & Yes & Yes & yes & yes & yes & yes & yes & yes & yes & non & green \\
\hline
\end{tabular}

RC.- recurrence, BI.- brain invasion, IR.- inflammatory response, RF.- Rosenthal Fibers, Ma.- macrophages, Hma.- Hemosiderophages, DC.- dystrophic calcifications, WH.- wet keratin. CHL cholesterol, GR.- Granulomas. OF.- Color of the oil fluid content of the cyst structures.

Table 2 showed the clinical laboratory results from analysis between serum values vs oil fluid values. The ranges of glucose level were from 234 to 876 (median of 456.00). We observed that larger size tumors had higher levels of glucose, cholesterol and lipids than in the serum analysis. Gelatinase activity was observed in all samples assayed. The zymography assay revealed the presence of bands of about 62 and $72 \mathrm{kDa}$ which correspond to latent and active forms of MMP-2 (proMMP-2 and aMMP-2
respectively)(Figure 2). The latent form of this MMP was present in the samples from control subjects (lane 1 and 2), and in one Central Nervous Systems cancer patient sample (lane 5). An increase in MMP-2 enzymatic activity (aMMP-2) was observed in the CSF in a patient with CNS cancer (lane 3). Bands of $86 \mathrm{kDa}$ (active MMP-9) were identified in samples from the oil craniopharyngioma fluid as well as in the serum of the patient, with an evident increased enzymatic activity in cancer subjects (Fig. 2).

Table 2. Results of the diverse components studied in serum of the patients in relationship with the oil fluid of the cyst structures.

\begin{tabular}{|c|c|c|c|}
\hline & Range of Normal value & Median of serum Value & Median of oil fluid Value \\
\hline Glucose & $65.00-110.00 \mathrm{mg} / \mathrm{dL}$ & $149.0 \mathrm{mg} / \mathrm{dL}$ & $735.0 \mathrm{mg} / \mathrm{dL}$ \\
\hline Urea & $14.00-40 \mathrm{mg} / \mathrm{dL}$ & $24.0 \mathrm{mg} / \mathrm{dL}$ & $77.0 \mathrm{mg} / \mathrm{dL}$ \\
\hline Creatinine & $0.70-1.30 \mathrm{mg} / \mathrm{dL}$ & $1.20 \mathrm{mg} / \mathrm{dL}$ & $5.7 \mathrm{mg} / \mathrm{dL}$ \\
\hline Blood Urea Nitrogen (BUN) & $6.00-20.00 \mathrm{mg} / \mathrm{dL}$ & $6.0 \mathrm{mg} / \mathrm{dL}$ & $68.0 \mathrm{mg} / \mathrm{dL}$ \\
\hline Calcium & $8.60-10.20 \mathrm{mg} / \mathrm{dL}$ & $8.0 \mathrm{mg} / \mathrm{dL}$ & $35.0 \mathrm{mg} / \mathrm{dL}$ \\
\hline Phosphorus & $2.70-4.50 \mathrm{mg} / \mathrm{dL}$ & $2.0 \mathrm{mg} / \mathrm{dL}$ & $8.0 \mathrm{mg} / \mathrm{dL}$ \\
\hline Magnesium & $1.70-2.55 \mathrm{mg} / \mathrm{dL}$ & $1.9 \mathrm{mg} / \mathrm{dL}$ & $43.0 \mathrm{mg} / \mathrm{dL}$ \\
\hline Sodium & $136.00-145.00 \mathrm{mmol} / \mathrm{L}$ & $122.0 \mathrm{mmol} / \mathrm{L}$ & $276.0 \mathrm{mmol} / \mathrm{L}$ \\
\hline Potassium & $3.50-4.50 \mathrm{mmol} / \mathrm{L}$ & $2.3 .0 \mathrm{mmol} / \mathrm{L}$ & $30.0 \mathrm{mmol} / \mathrm{L}$ \\
\hline Chlorine & $98.00-107.00 \mathrm{mmol} / \mathrm{L}$ & $114.0 \mathrm{mmol} / \mathrm{L}$ & $189.0 \mathrm{mmol} / \mathrm{L}$ \\
\hline Alkaline Phosphatase & $32.00-92.00 \mathrm{UI} / \mathrm{L}$ & $120.0 \mathrm{UI} / \mathrm{L}$ & $652.0 \mathrm{UI} / \mathrm{L}$ \\
\hline SerumGlutamicOxaloaceticTransaminase & $10.00-42.00 \mathrm{UI} / \mathrm{L}$ & $15.0 \mathrm{UI} / \mathrm{L}$ & $236.0 \mathrm{UI} / \mathrm{L}$ \\
\hline SerumGlutamicPyruvateTransaminase & $10.00-40.00 \mathrm{UI} / \mathrm{L}$ & $12.0 \mathrm{UI} / \mathrm{L}$ & $58.0 \mathrm{UI} / \mathrm{L}$ \\
\hline Gamma glutiltranferasa & $8.00-37.00 \mathrm{UI} / \mathrm{L}$ & $60.0 \mathrm{UI} / \mathrm{L}$ & $89.0 \mathrm{UI} / \mathrm{L}$ \\
\hline Total Bilirrubin & $0.20-1.00 \mathrm{mg} / \mathrm{dL}$ & $0.40 \mathrm{mg} / \mathrm{dL}$ & $5.0 \mathrm{mg} / \mathrm{dL}$ \\
\hline Total Protein & $6.40-8.30 \mathrm{~g} / \mathrm{dL}$ & $4.68 \mathrm{~g} / \mathrm{dL}$ & $35.0 \mathrm{~g} / \mathrm{dL}$ \\
\hline Albumin & $3.90-5.10 \mathrm{~g} / \mathrm{dL}$ & $2.56 \mathrm{~g} / \mathrm{dL}$ & $22.0 \mathrm{~g} / \mathrm{dL}$ \\
\hline Globulin & $2.90-3.30 \mathrm{~g} / \mathrm{dL}$ & $2.30 \mathrm{~g} / \mathrm{dL}$ & $23.0 \mathrm{~g} / \mathrm{dL}$ \\
\hline Cholesterol & $170-200 \mathrm{mg} / \mathrm{dL}$ & $120.0 \mathrm{mg} / \mathrm{dL}$ & $402.0 \mathrm{mg} / \mathrm{dL}$ \\
\hline Low density lipids & $100-130 \mathrm{mg} / \mathrm{dL}$ & $160.0 \mathrm{mg} / \mathrm{dL}$ & $478.0 \mathrm{mg} / \mathrm{dL}$ \\
\hline High density lipids & 40-50mg/dL. & $96.0 \mathrm{mg} / \mathrm{dL}$ & $689.0 \mathrm{mg} / \mathrm{dL}$ \\
\hline
\end{tabular}

Table showed the median of the results in oil fluid of craniopharyngioma cyst structures in relations ship with the median value of serum of the patients. 

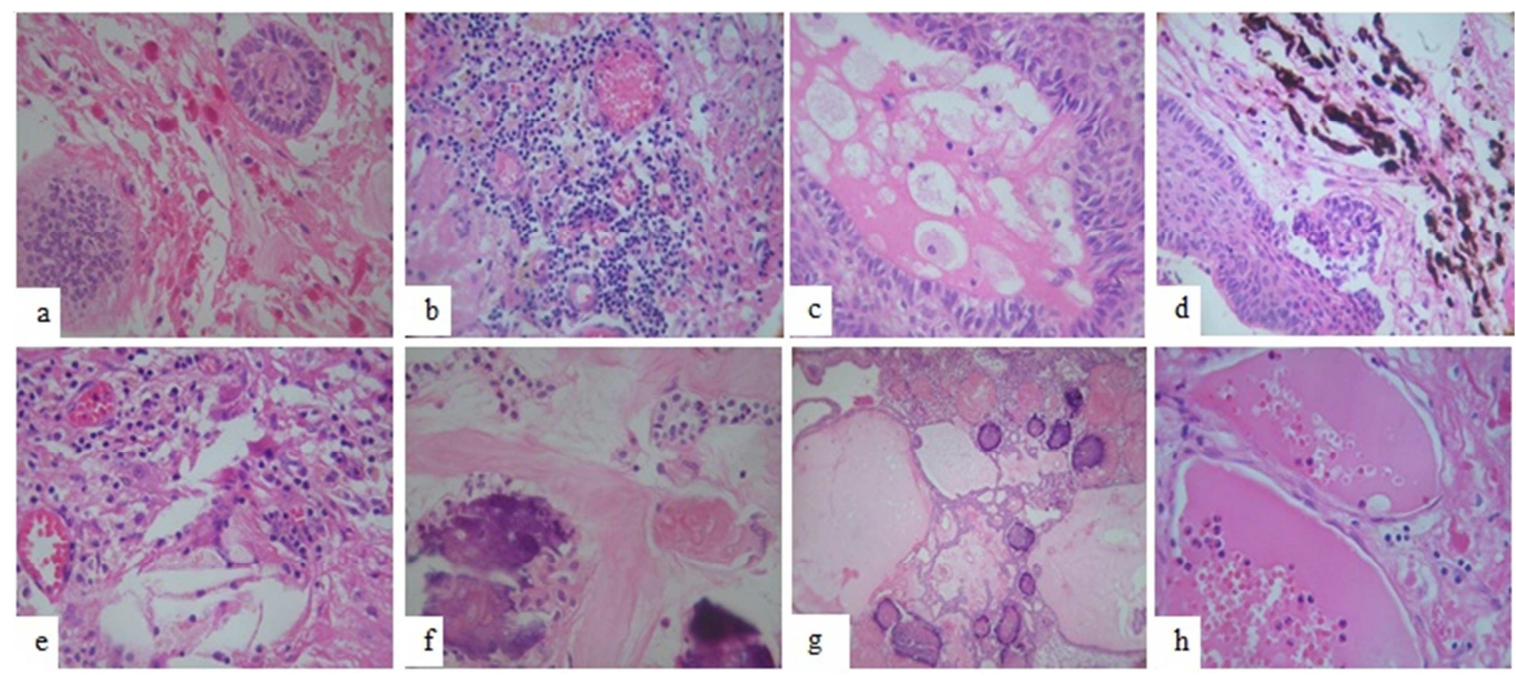

Figure 1. Histopathology features in craniopharyngioma. In (a) we can observe brain invasion, (b) inflammation, (c) macrophages, some of those with rupture of cytoplasm, (d) hemosiderin and hemosiderophages, (e) clef cholesterol and granulomas formation, (f) dystrophic calcification and wet keratins, and in (g) is observed the cyst structures that contain proteinaceous material $(H \& E x 200)$ and in $(h)$ is observed the oil proteinaceous material in the lumen of somevessels (H\&Ex400).

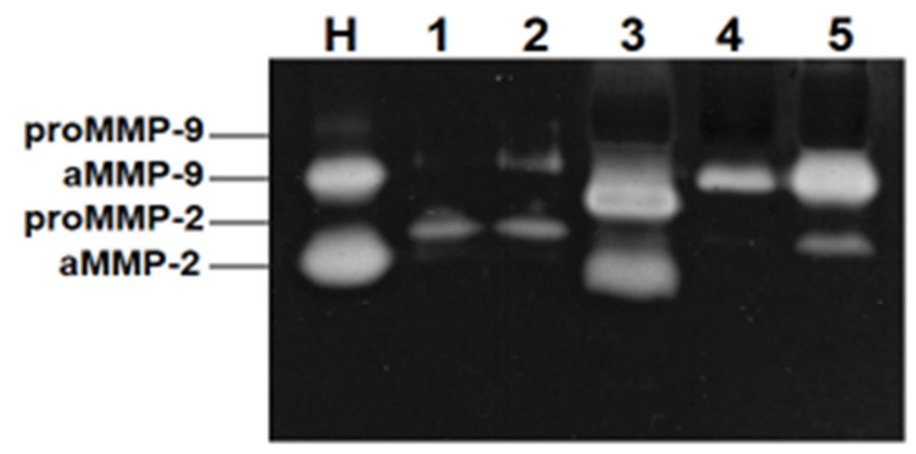

Figure 2. Zymography assay of CSF (cerebrospinal fluid) from CNS (central nervous system) patients. CSF from healthy subjects shows the latent form of $M M P-2$ (proMMP-2) (lane 1 and 2). A light band corresponds to active MMP-9 (aMMP-9) present in one of the healthy CSF samples. High MMP-9 activity was observed in oil craniopharyngioma fluid (lanes 3 and 5). A band which corresponds to aMMP-9 is also present in CSF from oil fluid of craniopharyngioma patient but with less enzymatic activity (lane 4). A high MMP-2 activity is observed in CNS cancer patient sample in lane 3. ProMMP-2 was visualized in CSF from cancer patient in lane 5. Control gel: $H=H T 1080$ fibrosarcoma cells medium.

\section{Discussion}

CFs can present as a suprasellar cystic lesion with a varied imaging appearance. In magnetic resonance imaging (MRI) using T1-weighted sequence, the cyst can show hypointense, isointense or hyperintense signals depending on the cyst content. ${ }^{8}$ Turbid and less viscous cyst content and heterogeneous $\mathrm{T} 1$ and/or T2 signals on MRI sometimes represented predominance of squamous epithelium in the cyst wall. Differences have been described between the oil fluid characteristics due to the presence of proteins, cholesterol, ${ }^{7,8}$ etc. We analyzed it and determined that depending on the biochemical components of the fluid, it can change its color and density. We observed yellow oil fluids contain less proteins, cholesterol, glucose and low density lipids compared to green oil fluid which have higher density and quantities of all elements studied. These changes are related to the radiological characteristics.

However, the cysts may have very high concentrations of protein. Along with high protein concentration in vitro, the signal intensity of MRI in T1-weighted images increased, while that of T2-weighted images decreased. In contrast, the cholesterol concentration sequence influenced the signal intensity of neither T1- nor T2-weighted images. ${ }^{9}{ }^{10}$ Lesions displaying hypointensity on T1-weighted images (T1WI) and hyperintensity on T2-weighted images (T2WI) contained CSF-like fluid. Cases showing hyperintensity on T1WI and isointensity on T2WI frequently contained mucoid material. ${ }^{9}$ Hyperintensity on both T1WI and T2WI suggest the presence of blood. A small area of hypo- or isointensity indicate thickening of the natural history of $\mathrm{CF}^{9,10}$ Now, it is poorly understood but high rates of recurrence after surgical resection have been reported. ${ }^{9-12}$

The tumor is often soft, with yellowish, oily fluid, also called "oil machinery" which is obtained from cyst content. Little is known about the characteristic of the oil machinery fluid of craniopharyngioma, biochemically studied regarding total protein, albumin, immunoglobulins $\mathrm{G}$ and $\mathrm{M}$ contents, lactate and $\mathrm{pH}$ and elevated lactate content and decreased $\mathrm{pH}$ in cyst fluids compared with blood serum. ${ }^{13}$ Higher mucopolysaccharides or hemosiderin levels of degradation 
product are presented, they can spill out from the cyst causing the granulomatous reaction. ${ }^{14}$

Histochemical investigation has revealed mucin secretion in microcysts, and electron microscopy has demonstrated zymogen granules in the epithelial cell; Morphological studies suggest that cystic craniopharyngiomas have a secretory component in addition to the classical histological structures. ${ }^{14}$ We observed epithelial cells can also produce lipids, as the fluted cells.

The two proteomic approaches for the characterization of craniopharyngioma intracystic fluid have been studied. Apolipoprotein A-I, A-II, C-I and J, hemoglobin fragments, ubiquitin, $\alpha$-2-HS-glycoprotein or fetuin A, $\alpha-1$ antichymotrypsin, vitamin D binding protein, and $\alpha-1$-acid glycoprotein have been characterized. ${ }^{15,16}$

The presence of $\beta$-thymosins in the intracystic tumor fluid was confirmed in the secretion of these proteins in the extracellular environment. ${ }^{16}$ Due to their G-actinsequestering activity, antiapoptotic and anti-inflammatory properties, these peptides could be strictly involved in tumor progression and cyst development and growth. ${ }^{16}$ The proteomic characterization of the intracystic tumoral fluid could contribute to the comprehension of the tumorigenesis processes and the development of therapeutic targets to reduce cyst volume, allowing less invasive surgery and/or delay radical resection of the tumor mass and decreasing collateral serious effects. ${ }^{17}$ Proteins and peptides involved in inflammation, mineralization processes and lipid transport are identified, in agreement with the calcium flecks, cholesterol granules and bone residues characteristic of this fluid. ${ }^{18}$ We observe calcium, cholesterol, glucose, low and high density lipids and transaminases levels are elevated in the oil cyst fluid compared with serum levels. The output of this fluid can occasion CNS damage which is not well known. We considerate this elements elevated and by their own they can produce inflammation or materials' deposit disturbing the healthy tissues surrounding it.

Surgical drainage and biopsy of the cyst wall or surgical cyst excision, are most frequently done through a transsphenoidal approach considered for symptomatic patients. Histologically, inflammation, macrophages, hemosiderophages and cholesterol clefts are often observed in craniopharyngioma and in Rathke's cleft cyst. ${ }^{1,14} \mathrm{CFs}$ have a tendency to invade surrounding structures and recur after a seemingly total resection. However, more recently, such an enhancement has been recognized to occur in non-neoplastic cysts and represent pericystic inflammation, squamous metaplasia, hemosiderin, cholesterol deposits, Rosenthal Fibers formation and macrophages. ${ }^{18}$ During the surgery we considerate, the liquid spills out to the CNS causing damage. This is evident because of the higher expression of 2 and 9 metalloproteins, macrophages, hemosiderophages, dystrophic calcifications, wet keratin, etc. in the oil fluid and in the surrounding brain tissue. The injured brain tissue is characterized by inflammatory cells, hemosiderophages, reactive gliosis, Rosenthal Fibers formation, blood vessels formation, which can be directly related with the presence of the oily fluid.

Compression of pituitary gland and increased intracystic pressure may damage mucous-producing goblet cells in the cyst wall, causing a reduced secretion with resultant decrease in the cyst size. ${ }^{13}$ Others mechanism postulated suggest that repeated cyst rupture ultimately leads to the shrinkage of the lesion. Chemical meningitis is a rare phenomenon due to craniopharyngioma's cyst rupture; it develops because of presence of cholesterol crystals in the cyst fluid secreted by the squamous epithelium lining of the cyst. Spontaneous rupture of the cyst may be presented with or without meningitis, depending upon the cholesterol contents of cystic fluid of tumor. ${ }^{19}$ Chronic inflammatory reaction is caused by extravasated cyst content into the adjacent gland and brain, ${ }^{19}$ and the inflammatory thromboembolic complication after craniopharyngioma surgery has been described. ${ }^{20}$ The estimation of free radical formation levels and malondialdehyde (MDA) concentration in cyst fluid seems to be a prognostic tool for the tumor recurrence. ${ }^{21} \mathrm{We}$ consider independent of the surgery used, there is a mechanism of cyst rupture, in which the oil fluid spills in the brain tissue, conditioning hypothalamus and hypophysis damage. The oily fluid spilled in these regions could cause obesity and endocrine disturbance like we observe in this craniopharyngioma patients.

Most of the patients diagnosed with a craniopharyngioma survive long-term, but they suffer many disease/treatment consequences. Among the metabolic consequences, there is a high prevalence of panhypopituitarism and diabetes insipidus, mainly due to the surgical treatment. ${ }^{22}$ Hypothalamic involvement can derive by infiltration of the tumor itself. Obesity is also more prevalent in these patients than in the general population, and gets worse with time. It is a consequence of a diminished basal metabolic rate and a lower physical activity compared to matched controls, with a similar or lower caloric intake. ${ }^{23}$

Most patients (85-95\%) suffer from multiple function disturbances in the hypothalamic-pituitary axis, ranging to complete pituitary insufficiency. ${ }^{24}$ This practice is considered critical to prevent peri-operative complications associated with hypoadrenalism, such as hypotension and circulatory collapse, ${ }^{22}$ hyponatremia, ${ }^{23}$ hyperinsulinemia and insulin resistance action., ${ }^{4,5}$ Dysregulation of the autonomic nervous system is thought to be involved in craniopharyngioma related hypothalamic obesity $(\mathrm{CRHO}){ }^{22}$ All these changes described can be related to the oil fluid extravasated, which breaks the blood brain barrier, and alters the extracellular matrix observed with the 2 and 9 metalloproteines presence.

In craniopharyngioma, the weight gain can principally occur because of the disruption of the normal homeostatic function of the hypothalamic centers responsible of controlling satiety and hunger and regulating energy balance. ${ }^{4,5}$ Nevertheless, the disturbance of hypothalamic structures by the tumor and/or its treatment considered the major pathogenic factor for hyperphagia and obesity, confirmed by an imaging study assessment of the extent of 
hypothalamic involvement and consequential sequelae. ${ }^{24}$ Animal studies suggest that hypothalamic obesity can also result from an increased parasympathetic and decreased sympathetic activity. Lesions of the ventromedial nuclei may lead to disinhibited or increased vagal tone resulting in hyperinsulinemia. $^{25}$

\section{Conclusions}

In this work we can conclude the cyst oil fluid contains high quantities of elements, compared to serum levels. These elements can spill out and be toxic for the brain tissue conditioning a large inflammatory reaction. This inflammatory reaction characterized by macrophagic cells incapable to phagocyte can injure the Central Nervous Systems. We consider the presence of the fluid rich in cholesterol and lipids can occasion deposits permitting an irritation in the hypothalamus/hypophysis developing obesity and endocrine disturbances. If there is more brain damage it is associated with an increased amount of oil content.

\section{References}

[1] Louis DN, Ohgaki H, Wiestler OD, Cavenee WK, Burger PC, Jouvet A, Scheithauer BW, Kleihues P. The 2007 WHO Classification of Tumours of the Central Nervous System. ActaNeuropathol (Berl) 2007; 114:97-109.

[2] Sekine S, Takata T, Shibata T, et al. "Expression of enamel proteins and LEF1 in adamantinomatous craniopharyngioma: evidence for its odontogenic epithelial differentiation". Histopathology 2004; 45 (6): 573-9.

[3] Müller H. L. Consequences after craniopharyngioma surgery in children. J. Clin. Endocrinol. Metab. 2011; 96, 1981-1991

[4] Müller H. L., Albanese A., Calaminus G., Hargrave D., Garré M. L., Gebhardt U., Saran F., Sörensen N., Spoudeas H. A. Consensus and perspectives on treatment strategies in childhood craniopharyngioma - results of a meeting of the craniopharyngioma study group (SIOP), Genova 2004. J. Pediatr. Endocrinol. Metab. 2006a; 19, 453-454

[5] Hamid R, Sarkar S, Hossain MA, Mazumder U, Akanda NI, Parvin $\mathrm{R}$ "Clinical picture of craniopharyngioma in childhood". Mymensingh medical journal. 2007; 16: 123-6.

[6] Ahmet A, Blaser S, Stephens D, Guger S, Rutkas JT, Hamilton J. Weight gain in craniopharyngioma; a model for hypothalamic obesity. J PediatrEndocrinolMetab. 2006;19:121-127.

[7] Ikeda H, Yoshimoto T. Clinicopathological study of Rathke's cleft cysts. . ClinNeuropathol. 2002; 21: 82-91.

[8] Gutierrez LP, Koltowska-Haggstrom M, Jonsson PJ, Mattsson AF, Svensson D, Westberg B \& Luger A. Registries as a tool in evidence-based medicine: example of KIMS (Pfizer International Metabolic Database). Pharmacoepidemiology and Drug Safety 200817 90-102.

[9] Chatterjee S, Kesavadas C, Menon G, Nair S, Radhakrishnan VV. Changing signal intensity of a craniopharyngioma. Neurol India. 2010; 58:468-70.
[10] Hayashi Y, Tachibana O, Muramatsu N, Tsuchiya H, Tada M, Arakawa Y, Suzuki M, Yamashita J. Rathke cleft cyst: MR and biomedical analysis of cyst content. . J Comput Assist Tomogr. $1999 ; 23: 34-38$.

[11] Smith PK, Krohn RI, Hermanson GT, Mallia AK, Gartner FH, Provenzano MD, Fujimoto EK, boeke NM, Olson BJ, Klenk DC. Measurement of protein using bicinchoninic acid Anal Biochem 1985; 150:76-85.

[12] Vadillo-Ortega F, González-Avila G, Furth EE, Lei H, Muschel RJ, Stetler-Stevenson WG, Strauss III JF. 92-kd Type IV collagenase (matrix metalloproteinase-9) activity in human amniocorion increases with labor. Am J Pathol 1995; 146:148156.

[13] Arefyeva IA, Semenova JB, Zubairaev MS, Kondrasheva EA, Moshkin AV. Analysis of fluid in craniopharyngioma-related cysts in children: proteins, lactate and pH.ActaNeurochir (Wien). 2002; 144:551-54.

[14] Hama S, Arita K, Nishisaka T, Fukuhara T, Tominaga A, Sugiyama K, Yoshioka H, Eguchi K, Sumida M, Heike Y, Kurisu K. Changes in the epithelium of Rathke cleft cyst associated with inflammation. J Neurosurg. 2002; 96:209-16.

[15] Szeifert GT, Julow J, Szabolcs M, Slowik F, Bálint K, Pásztor E. Secretory component of cystic craniopharyngiomas: a mucino-histochemical and electron-microscopic study. Surg Neurol. 1991; 36: 286-93.

[16] Martelli C, Iavarone F, Vincenzoni F, Rossetti DV, D'Angelo L, Tamburrini G, Caldarelli M, Di Rocco C, Messana I, Castagnola M, Desiderio C. Proteomic characterization of pediatric craniopharyngioma intracystic fluid by LC-MS integrated approaches. Electrophoresis. 2014; 35:2172-83.

[17] Desiderio C, Martelli C, Rossetti DV, Di Rocco C, D'Angelo L, Caldarelli M, Tamburrini G, Iavarone F, Castagnola M, Messana I, Cabras T, Faa G. Identification of thymosins $\beta 4$ and $\beta 10$ in paediatri craniopharyngioma cystic fluid. Childs Nerv Syst. 2013; 29: 951-60.

[18] Yokoyama S, Goto M, Hirano H, Hirakawa W, Noguchi S, Hirahara K, Kadota K, Asakura T. Pituitary Adenoma with Cholesterol Clefts. EndocrPathol. 1998; 9:91-95.

[19] Rajput D, Srivastva A, Kumar R, Mahapatra A. Recurrent chemical meningitis in craniopharyngioma without reduction in size of cyst: case report of two cases and review of the literature. Turk Neurosurg. 2012; 22: 233-6.

[20] Fischer B, Palkovic S, Schildheuer D, Heindel W, Wassmann H. Inflammatory thromboembolic complication after craniopharyngioma surgery? ActaNeurochir (Wien). 2004; 146:183-6.

[21] Aref'eva IA, SemenovaZhB, Korshunov AG, Zubaŭraev MS, Krasnova TS, Gorelyshev SK, PromyslovMSh. Lipid peroxidation in the cyst fluid of craniopharyngiomas. Vopr Med Khim. 2001; 47:625-32.

[22] Müller HL, Gebhardt U, Schröder S, Pohl F, Kortmann R D, Faldum A, Zwiener I, Warmuth-Metz M, Pietsch T, Calaminus G, Kolb R, Wiegand C, Sörensen N. Analyses of treatment variables for patients with childhood craniopharyngioma results of the multicenter prospective study trial KRANIOPHARYNGEOM 2000 after three years of follow up. Horm. Res. Paediatr; 2010; 73: 175-180. 
[23] Müller H. L., Faldum A., Etavard-Gorris N., Gebhardt U., Oeverink R., Kolb R., Sörensen N. Functional capacity, obesity and hypothalamic involvement crosssectional study on 212 patients with childhood craniopharyngioma. Klin. Padiatr 2003a; 215: 310-314.

[24] DeVile CJ, Grant DB, Hayward RD, Stanhope R. Growth and endocrine sequelae of craniopharyngioma. Arch. Dis. Child. 1996a; 75: 108-114
[25] Puget S, Garnett M, Wray A, Grill J, Habrand JL, Bodaert N, Zerah M, Bezerra M, Renier D, Pierre-Kahn A, Sainte-Rose C. Pediatric craniopharyngiomas: classification and treatment according to the degree of hypothalamic involvement. J Neurosurg 2007; 106, 3-12. 